University of Nebraska - Lincoln

DigitalCommons@University of Nebraska - Lincoln

Agronomy \& Horticulture - Faculty Publications

Agronomy and Horticulture Department

9-16-2006

\title{
Nitrate Accumulation and Movement Under Deficit Irrigation in Soil Receiving Cattle Manure and Commercial Fertilizer
}

D. D. Tarkalson

University of Nebraska-Lincoln, david.tarkalson@ars.usda.gov

J. O. Payero

University of Nebraska-Lincoln, jpayero@clemson.edu

S. M. Ensley

lowa State University

Charles A. Shapiro

University of Nebraska-Lincoln, cshapiro1@unl.edu

Follow this and additional works at: https://digitalcommons.unl.edu/agronomyfacpub

Part of the Plant Sciences Commons

Tarkalson, D. D.; Payero, J. O.; Ensley, S. M.; and Shapiro, Charles A., "Nitrate Accumulation and Movement Under Deficit Irrigation in Soil Receiving Cattle Manure and Commercial Fertilizer" (2006). Agronomy \& Horticulture -- Faculty Publications. 341.

https://digitalcommons.unl.edu/agronomyfacpub/341

This Article is brought to you for free and open access by the Agronomy and Horticulture Department at DigitalCommons@University of Nebraska - Lincoln. It has been accepted for inclusion in Agronomy \& Horticulture -Faculty Publications by an authorized administrator of DigitalCommons@University of Nebraska - Lincoln. 
Published in Agricultural Water Management 85:1-2 (September 16, 2006), pp. 201-210; doi: 10.1016/j.agwat.2006.04.005

Copyright $(92006$ Elsevier B.V. Used by permission. http://www.elsevier.com/locate/agwat

A contribution of the University of Nebraska Agricultural Research Division, Lincoln, NE 68583. Journal Series No. 15074.

Revised April 30, 2006; published online June 12, 2006.

\title{
Nitrate accumulation and movement under deficit irrigation in soil receiving cattle manure and commercial fertilizer
}

\author{
D. D. Tarkalson, ${ }^{\mathrm{a}}$ J. O. Payero, ${ }^{\mathrm{b}}$ S. M. Ensley,, ${ }^{\mathrm{c}}$ and C. A. Shapiro ${ }^{\mathrm{d}}$ \\ a Department of Agronomy and Horticulture, University of Nebraska-Lincoln, \\ West Central Research and Extension Center, 461 West University Drive, North Platte, NE 69101 \\ ${ }^{b}$ Department of Biological and Agricultural Engineering, University of Nebraska-Lincoln, \\ West Central Research and Extension Center, 461 West University Drive, North Platte, NE 69101 \\ ${ }^{c}$ Department of Veterinary Diagnostic and Production Animal Medicine, Iowa State University, \\ 1600 South 16th Street, Ames, IA 50011 \\ d Department of Agronomy and Horticulture, University of Nebraska-Lincoln, \\ University of Nebraska Haskell Agricultural Laboratory, 57905866 Road, Concord, NE 68728 \\ Corresponding author - D. D. Tarkalson, tel 308 696-6709, fax 308 532-3823, email dtarkalson2@unl.edu
}

\begin{abstract}
Nitrate leaching from agricultural soils can increase groundwater nitrate concentrations. The objectives of the study were to assess the accumulation and movement of nitrate in the soil profile over a 2-year period under deficit irrigation conditions following a one time application of $\mathrm{N}$ in cattle feedlot manure and commercial fertilizer to corn at rates to achieve yield goals expected under conditions of full irrigation. Cattle manure and ammonium nitrate were applied in 2002 at the University of Nebraska recommended rate (1M and $1 \mathrm{~F}$, respectively) and cattle manure was applied at twice the recommended rate (2M) for $\mathrm{N}$ for the 2002 corn (Zea mays L.) crop. The recommended rate was based on expected yields under full irrigation. The manure $\mathrm{N}$ treatments were applied to percolation lysimeters and adjacent plots on a Cozad silt loam soil. Ammonium nitrate was applied only to the percolation lysimeters. Leachate from the lysimeters was extracted from a depth of $2.1 \mathrm{~m}$ and soil samples were collected from field plots in $0.3 \mathrm{~m}$ depth increments to $2.1 \mathrm{~m}$ on a periodic basis. Water available to the crop was sufficient to meet 89 and $79 \%$ of the potential crop ET in 2002 and 2003, respectively. When averaged over the manure $\mathrm{N}$ treatments, reduced ET resulted in grain yields that were approximately 2.1 and $2.7 \mathrm{Mg} \mathrm{ha}^{-1}$ less than expected in 2002 and 2003. Under deficit water inputs there was leachate movement below the root zone. Leachate depths averaged over $\mathrm{N}$ treatments were, however, reduced by 15\% (33 mm) in 2002 and $47 \%$ (102 mm) in 2003 compared with those reported under full irrigation. The average nitrate- $\mathrm{N}\left(\mathrm{NO}_{3}{ }^{-} \mathrm{N}\right)$ concentrations in leachate were higher under the $2 \mathrm{M}$ treatment $\left(41 \mathrm{mg} \mathrm{L}^{-1}\right)$ compared to the $1 \mathrm{M}$ treatment $\left(17 \mathrm{mg} \mathrm{L}^{-1}\right)$. The average $\mathrm{NO}_{3}^{-}-\mathrm{N}$ concentrations in leachate from the $1 \mathrm{~F}$ treatment $\left(28 \mathrm{mg} \mathrm{L}^{-1}\right)$ was not different than the 1 or $2 \mathrm{M}$ treatments. There were trends for greater $\mathrm{NO}_{3}{ }^{-}-\mathrm{N}$ mass losses in leachate averaged over all treatments in 2003 compared to 2002, indicating that $\mathrm{NO}_{3}{ }^{-}-\mathrm{N}$ derived from the 2002 application leached to at least $2.4 \mathrm{~m}$ below the soil surface. There were no mass loss differences in leachate due to the 2001 crop in 2002. In 2003, mass of $\mathrm{NO}_{3}{ }^{-} \mathrm{N}$ in lysimeters cropped to soybean in 2001 were significantly higher $\left(144 \mathrm{~kg} \mathrm{NO}_{3}^{-}-\mathrm{N} \mathrm{ha}^{-1}\right)$ than the mass in lysimeters cropped to corn in 2001 (51 $\left.\mathrm{kg} \mathrm{NO}_{3}{ }^{-}-\mathrm{N} \mathrm{ha}^{-1}\right)$. Nitrate-N mass increased in the 0.9-2.1 m soil depth 12-13 months after manure $\mathrm{N}$ treatment applications. The $2 \mathrm{M}$ treatment had greater soil $\mathrm{NO}_{3}{ }^{-}-\mathrm{N}$ mass than the $1 \mathrm{M}$ treatment for most sampling dates in the surface $0.9 \mathrm{~m}$. This research shows that there can be significant nitrate losses under deficit irrigation when manure $\mathrm{N}$ is over applied. These losses are likely related to water initially stored below the root zone and preferential flow of water from irrigation and precipitation. Determining accurate yield expectations under deficit irrigation conditions, correct scheduling of irrigation, and the use current best management practices for $\mathrm{N}$ management can help minimize nitrate losses in leachate.
\end{abstract}

Keywords: plant available nitrogen, evapotranspiration, deficit irrigation, corn, maize, nitrogen, leaching, percolation lysimeter 


\section{Introduction}

In the Midwest and Central Great Plains of the USA, expected yield is often considered in determining nitrogen application rates for corn because yield level is related to N uptake (Ferguson et al., 1991). Determining an accurate yield goal becomes critical under these circumstances in order to prevent under and over application of $\mathrm{N}$. Under applying $\mathrm{N}$ results in decreased yields and profits while over application can potentially increase nitrate- $\mathrm{N}\left(\mathrm{NO}_{3}{ }^{-}-\mathrm{N}\right)$ accumulation in soils and potential losses to ground and surface waters. Achievable crop yields are also related to the amount of water available for crop evapotranspiration (ET). If water inputs do not meet the crop ET demand, yields will be reduced (Schneekloth et al., 1991; Payero et al., 2005, 2006). Due to water shortages and limited water allocations in many areas in the Great Plains, determining an accurate yield goal and the corresponding $\mathrm{N}$ application rate can be difficult due to variation in natural precipitation amounts and timing. For example, many farmers in western and west central Nebraska are facing challenges with reduced availability of irrigation water due to: (1) considerable declines in groundwater levels in the High Plains Aquifer (McGuire and Fischer, 1999; McGuire, 2004), (2) The Endangered Species Act of 1973 requiring Nebraska to release a portion of stored water, which would otherwise be used for irrigation, to preserve habitats for several endangered species in the Platte River (Lingle and Franti, 1998), (3) restrictions in future water use from the basin that were imposed as a result of a recent out-of-court settlement between Nebraska and Kansas, and (4) drought conditions that have decreased water stored in reservoirs to record low levels. This situation has forced irrigation districts to severely limit or cease water deliveries to irrigators. Also, several areas of western and west central Nebraska have implemented water allocation programs for agricultural land irrigated from ground water. Under these conditions the potential to under and over apply $\mathrm{N}$ increases due to difficulty in determining an accurate yield goal as a result of an uncertainty of the precipitation and irrigation water availability. It is important to conduct research to assess the impacts of $\mathrm{N}$ management under deficit irrigation conditions.

In Nebraska there are over 2.1 million cattle on feed that produce approximately 5.6 million tonnes of manure annually (Eghball, 1998). Manure from livestock production can serve as a valuable source of $\mathrm{N}$ for fields in corn production that are in close proximity to confined feeding operations, but inefficient use can result in excessive losses of $\mathrm{NO}_{3}{ }^{-}-\mathrm{N}$ to surface and ground water. Nitrate movement to ground water is a concern in many agricultural areas receiving $\mathrm{N}$ inputs from both manure and chemical fertilizer (Jokela, 1992). These concerns are even more relevant in areas where ground water is a major source of drinking water. High $\mathrm{NO}_{3}^{-}{ }_{-}^{-}$ $\mathrm{N}$ in drinking water supplies is a health concern (Keeney, 1982). In Nebraska, $80 \%$ of the public water supply comes from ground water (U.S. Dept. Interior, 1999). A study conducted in Nebraska found that $19 \%$ of over 1800 domestic wells tested exceeded the maximum contaminant level of $10 \mathrm{mg} \mathrm{NO}_{3}^{-}-\mathrm{N} \mathrm{L}^{-1}$ imposed by the U.S. Environmental Protection Agency (EPA) (Gosselin et al., 1997). A major source of these nitrates has been associated with nitrogen fertilizer used in crop production (Owens et al., 1995).

Most feedlot cattle manure in Nebraska is spread on corn fields as a solid in the fall or spring prior to planting and is either left on the surface or incorporated. Based on the Nebraska Department of Environmental Quality (NDEQ) Title 130, animal feeding operations that are required to have a nutrient management plan that calculates plant available $\mathrm{N}$ (PAN), cannot apply manure in excess of the current year's corn $\mathrm{N}$ requirement (NDEQ, 2005). Prior to livestock waste control regulations that were established in 1998, over application of manure likely occurred to land cropped to corn in some areas.

The determination of crop available $\mathrm{N}$ from manures is based on the contents of $\mathrm{NH}_{4}{ }^{+}, \mathrm{NO}_{3}{ }^{-}$, and organic $\mathrm{N}$ in the manures. Solid manures such as cattle manure collected from feedlot surfaces have a large proportion of the $\mathrm{N}$ in the organic fraction. When determining the crop available $\mathrm{N}$ in these manures, an availability factor is used to estimate the percent of the organic $N$ that will be available to the crop during the first and subsequent growing seasons. Mineralization of organic $\mathrm{N}$ is a result of microbial decomposition of the organic material, which is influenced by the type of organic material, soil moisture, temperature, and oxygen content. These factors vary both spatially and temporally making it difficult to determine exact availability factors from site to site and year-to-year. Therefore, regional estimates of these values have been complied by reviewing the relevant literature (MidWest Plan Service, 1998).

Past research has determined that the mineralization rates of organic $\mathrm{N}$ from manure can range from 1 to $50 \%$ (Power and Doran, 1984). Hartz et al. (2000) determined that over a 3-month period, approximately $13 \%$ of the organic $\mathrm{N}$ mineralized from non-composted aged cattle feedlot manure. If the manure was composted, the 3month availability factor was reduced to approximately $5 \%$. Klausner et al. (1994) determined that the annual decay series of organic $\mathrm{N}$ from dairy manure was 21,9 , 3 , and $2 \%$ over a 4 -year period. Chang and Janzen (1996) concluded that over a 21-year period of annual applications of feedlot manure to irrigated barley the available $\mathrm{N}$ from the mineralization of organic $\mathrm{N}$ was $56 \%$. There were no differences in mineralization rates for incorporation and surface applications. The University of Nebraska recommends that animal producers and farmers assume that approximately $25 \%$ of the organic $\mathrm{N}$ in 
feedlot solid manure will be available to corn the first growing season after application (Koelsch and Shapiro, 2006). This factor was obtained from published recommendations from the MidWest Plan Service (MidWest Plan Service, 1998). The uncertainty and variability in $\mathrm{N}$ mineralization from organic $\mathrm{N}$ increases the risk of under or over application of $\mathrm{N}$.

In many areas of the Central Great Plains, drought and increased water demands are resulting in deficit irrigation situations. When irrigation amounts do not to meet crop ET demands, $\mathrm{N}$ application rates based on full irrigation (irrigation is applied to supplement precipitation and stored soil water to ensure the crop is never under water stress) could result in an over application of $\mathrm{N}$ and the potential for future $\mathrm{NO}_{3}{ }^{-}$losses to groundwater if water moves through the soil. The accumulation and movement of $\mathrm{NO}_{3}{ }^{-}$in soil as a result of manure $\mathrm{N}$ applications and mineralization under deficit irrigation conditions in semi-arid environments needs to be assessed. Currently it is unknown what effect deficit irrigation has on manure $\mathrm{N}$ mineralization, and water and nitrate movement through the soil profile. Management recommendations are needed for crop producers and feedlot operators who have limited water supplies. The objectives of the study were to assess the accumulation and movement of nitrate in the soil profile over a 2-year period under deficit irrigation conditions following a one time application of $\mathrm{N}$ in cattle feedlot manure and commercial fertilizer to corn at rates to achieve yield goals expected under conditions of full irrigation.

\section{Materials and methods}

This field study was conducted from 2002 to 2003 on a Cozad silt loam soil (fine-silty, mixed, mesic Fluventic Haplustoll) cropped to corn at the University of Nebraska West Central Research and Extension Center (WCREC) in North Platte, NE. Twelve monolithic nonweighing lysimeters measuring $0.9 \mathrm{~m}$ in diameter and $2.4 \mathrm{~m}$ deep and 12 plots $(6.1 \mathrm{~m} \times 12.2 \mathrm{~m})$ located adjacent to each lysimeter were used for the study. The lysimeters were installed in 1981 from undisturbed soil columns collected from the research site. A detailed description of the lysimeter characteristics was given by Klocke et al. (1993). Nitrogen was applied as manure and commercial fertilizer (ammonium nitrate) to the percolation lysimeters and adjacent plots. Manure treatments applied in 2002 consisted of cattle manure applied at the recommended rate $(1 \mathrm{M})$ and cattle manure at twice the recommended rate (2M) for $\mathrm{N}$ for the 2002 corn crop. Ammonium nitrate was applied at the recommended rate for $\mathrm{N}(1 \mathrm{~F})$. The recommended $\mathrm{N}$ application rates were based on soil analysis and the University of Nebraska $\mathrm{N}$ fertilizer recommendations for fully irrigated corn (Shapiro et al., 2003).
Cattle manure was collected from cattle pens located at the WCREC in the spring of 2002 and analyzed for total $\mathrm{N}$ content using the total Kjeldahl nitrogen method (Bremner and Mulvaney, 1982), and $\mathrm{KCl}$ extractable $\mathrm{NH}_{4}{ }^{+}$and $\mathrm{NO}_{3}{ }^{-}$(Keeney and Nelson, 1982) (Table 1). At the time of manure collection, the manure was dry (approximately $10 \%$ moisture content) due to lack of precipitation. In order to prevent organic $\mathrm{N}$ transformations after manure samples for $\mathrm{N}$ analysis were collected, and to prevent increases in moisture in the manure due to precipitation, manure was spread evenly on a cement floor under a covered barn to a uniform depth of $0.3 \mathrm{~m}$. The recommended and twice the recommended $\mathrm{N}$ rate for the research site were 197 and $394 \mathrm{~kg} P A N ~ h a^{-1}$, respectively. The application rates for manure were $62 \mathrm{Mg} \mathrm{ha}^{-1}$ $(1 \mathrm{M})$ and $124 \mathrm{Mg} \mathrm{ha}^{-1}(2 \mathrm{M})$ on an 'as received' basis. These application rates of manure are equivalent to 197 and $394 \mathrm{~kg}$ PAN ha ${ }^{-1}$ based on $95 \%$ available $\mathrm{NH}_{4}^{+}$ and $25 \%$ available organic $\mathrm{N}$ in the first growing season (MidWest Plan Service, 1998). The three treatments were replicated four times in a completely randomized design. On 9 May 2002, the treatments were applied to the lysimeters and field plots and incorporated with a hand gardening trowel (lysimeter) and disc (plots) to a depth of approximately $0.1 \mathrm{~m}$. In 2003, the lysimeters and plots for both treatments did not receive additional $\mathrm{N}$ inputs. Corn was planted to the lysimeters and plots on 13 May in both 2002 and 2003.

In the year prior to the initiation of this study, six lysimeters and adjacent field plots were cropped to corn, and six were cropped to soybean [Glycine max (L.) Merr.]. Each treatment had two replications under the previous corn crop and two replications under the previous soybean crop. This allowed statistical analysis to determine the influence of the previous crop on measured factors in leachate and soil.

Table 1. Analysis of beef feedlot manure in 2002

\begin{tabular}{lcccc}
\hline & Analysis & Applied (kg ha) & \multicolumn{3}{c}{ Available (kg ha) } \\
$2002^{\mathrm{a}}$ & $2003^{\mathrm{a}}$ \\
\hline Moisture & 10.4 & & - & - \\
Total N & 0.88 & 547 & - & - \\
Organic N & 0.74 & 460 & 115 & 55 \\
Ammonium N & 0.14 & 87 & 82 & - \\
$\mathrm{NO}_{3}^{-}-\mathrm{N}^{\mathrm{b}}$ & 0.001 & 0.6 & - & - \\
$\mathrm{Pc}^{\mathrm{C}}$ & 0.6 & 372 & - & - \\
$\mathrm{K}^{\mathrm{c}}$ & 1.1 & 684 & - & - \\
$\mathrm{Ca}$ & 1.6 & 995 & - & - \\
$\mathrm{Mg}$ & 0.55 & 342 & - & - \\
$\mathrm{Na}$ & 0.13 & 81 & - & - \\
$\mathrm{C}: \mathrm{N}$ & $12: 1$ & - & - & - \\
\hline
\end{tabular}

Analysis is based on the average of two samples and is reported on an "as received" basis.

a Based on $1 \mathrm{M}$ treatment. Availability factors of $25 \%$ for organic $\mathrm{N}$ and $95 \%$ for ammonium $\mathrm{N}$ in year 1 (2002) and $2 \%$ for organic $\mathrm{N}$ in year 2 (2003).

b Assumed to be negligible and was not taken into account when determining the manure applications rates.

${ }^{\mathrm{c}}$ Based on elemental forms. 
In the two manure treatments, a composite sample of three soil cores (38 $\mathrm{mm}$ diameter) were collected from depths of $0-0.2,0.2-0.6,0-0.9,0.9-1.2,1.2-1.5,1.5-1.8$, and 1.8-2.1 m from each plot in 2002 on 11 April, 31 May, 19 June, 1 August, 16 September, 7 November, and on 1 May, 4 June, 24 July, and 28 October in 2003. Soil samples were air dried, ground to pass through a $2 \mathrm{~mm}$ sieve, and analyzed for $\mathrm{NO}_{3}{ }^{-}-\mathrm{N}$ concentration (Keeney and Nelson, 1982). Average bulk densities values determined in the spring of 2002 and the $\mathrm{NO}_{3}{ }^{-}$concentrations for each sampling depth were used to determine the mass of $\mathrm{NO}_{3}{ }^{-}$$\mathrm{N}$ in the soil for each sample date. The bulk densities for depths of $0-0.2,0.2-0.6,0-0.9,0.9-1.2,1.2-1.5,1.5-1.8$, and $1.8-2.1 \mathrm{~m}$ were $1.33,1.30,1.35,1.29,1.31,1.31$, and $1.31 \mathrm{~g} \mathrm{~cm}^{-3}$, respectively. Soil samples were not obtained from the lysimeters in order to maintain the integrity of the soil core. Soil analyses from the $1 \mathrm{~F}$ treatment were not presented due to potential error in fertilizer application rates to field plots. Ammonium nitrate was applied to the percolation lysimeters but not to the adjacent field plots.

Leachate was collected from the lysimeters periodically throughout the study period based on the input of water to the system and the level of leachate in the collection pan at the bottom of the lysimeters. The total leachate volume was recorded at each sampling time and a $500 \mathrm{ml}$ sub-sample was obtained from each lysimeter and for each sampling date and analyzed for $\mathrm{NO}_{3}{ }^{-}$$\mathrm{N}$ concentration using the copperized cadmium reduction method (Keeney and Nelson, 1982). The leachate volumes and concentrations of $\mathrm{NO}_{3}{ }^{-} \mathrm{N}$ in leachate for each sampling date were used to determine the mass losses of $\mathrm{NO}_{3}{ }^{-}-\mathrm{N}$ below $2.1 \mathrm{~m}$. The leachate volume in liters collected was converted to a water depth as follows:

$$
\text { Leachate Depth }(\mathrm{mm})=\mathrm{LV} / A
$$

where $\mathrm{LV}$ is the volume of leachate $(\mathrm{L})$ and the $A$ is the area of the percolation lysimeter $\left(\mathrm{m}^{2}\right)$.

The $\mathrm{NO}_{3}^{-}-\mathrm{N}$ mass in leachate was determined as follows:

$$
\mathrm{NO}_{3}{ }^{-}-\mathrm{N} \text { mass }\left(\mathrm{kg} \mathrm{ha}^{-1}\right)=\left[\mathrm{NO}_{3}{ }^{-}-\mathrm{N}_{\mathrm{L}}\right] \times \mathrm{LV} / A \times 0.01
$$

where $\left[\mathrm{NO}_{3}{ }^{-}-\mathrm{N}_{\mathrm{L}}\right]$ is the concentration of $\mathrm{NO}_{3}{ }^{-} \mathrm{N}$ in leachate $\left(\mathrm{mg} \mathrm{L}^{-1}\right)$, $\mathrm{LV}$ the leachate volume $(\mathrm{L}), A$ the area of the percolation lysimeter $\left(\mathrm{m}^{2}\right)$ and 0.01 is the conversion factor from $\mathrm{mg} \mathrm{m}^{-2}$ to $\mathrm{kg} \mathrm{ha}^{-1}$.

The percent root zone water depletion data were calculated daily during the growing season in 2002 and 2003 using a computer model (Payero et al., 2005). The model used the dual crop coefficient method described by Wright (1982) and Allen et al. (1998) to calculate crop water use. The model calculated the daily soil water balance for $1.7 \mathrm{~m}$ soil depth based on weather, crop, and soil information. Weather data (precipitation and all the variables needed to calculate reference evapotranspiration, such as solar radiation, relative humidity, air temperature, and wind speed) were obtained from an automatic weather station located near the study site. It also calculated the actual cumulative crop evapotranspiration $\left(\mathrm{ET}_{\mathrm{d}}\right)$ and the estimated cumulative crop ET assuming water was not limiting $\left(\mathrm{ET}_{\mathrm{w}}\right)$. Both $\mathrm{ET}_{\mathrm{d}}$ and $\mathrm{ET}_{\mathrm{w}}$ were determined from corn emergence to physiological maturity.

Irrigation was provided by a solid set sprinkler irrigation system (Payero and Irmak, in press). Irrigation scheduling was based on applying approximately $75 \%$ of the estimated irrigation requirements.

Analysis of variance was conducted using the Completely Randomized Model from Statistix 8 (Analytical and Software, 2003). Main effects of $\mathrm{N}$ treatment, previous crop, and $\mathrm{N}$ treatment by previous crop interaction were determined for corn grain yields in 2002 and 2003. Main effects of $\mathrm{N}$ treatment, previous crop, year and interactions were determined for lysimeter leachate data. Main effects of manure $\mathrm{N}$ treatment, previous crop, date, and interactions were determined for soil $\mathrm{NO}_{3}{ }^{-} \mathrm{N}$ mass in the 0-0.9 and 0.9-2.1 m depths for sampling dates after manure application in both 2002 and 2003 separately. Treatment effects were determined for the pre-application sampling date (11 April 2003) to test for site uniformity. The $\mathrm{NO}_{3}{ }^{-}-\mathrm{N}$ masses for each depth increment were summed to give a total mass in the 0-0.9 and 0.9-2.1 $\mathrm{m}$ depths. The $\mathrm{NO}_{3}{ }^{-}-\mathrm{N}$ mass in soil at each depth was determined as follows:

$\mathrm{NO}_{3}{ }^{-}-\mathrm{N}$ mass $\left(\mathrm{kg} \mathrm{ha}^{-1}\right)=\mathrm{BD} \times \mathrm{SV} \times\left[\mathrm{NO}_{3}{ }^{-}-\mathrm{N}_{\mathrm{S}}\right] \times 10^{-6}(3)$ where $\mathrm{BD}$ is the bulk density of the soil $\left(\mathrm{kg} \mathrm{m}^{-3}\right)$, SV the soil volume $\left(\mathrm{m}^{3}\right),\left[\mathrm{NO}_{3}{ }^{-} \mathrm{N}_{\mathrm{S}}\right]$ the concentration of $\mathrm{NO}_{3}{ }^{-}$ $\mathrm{N}$ in soil $\left(\mathrm{mg} \mathrm{kg}^{-1}\right)$ and $10^{-6}$ is the conversion factor from $\mathrm{mg} \mathrm{ha}^{-1}$ to $\mathrm{kg} \mathrm{ha}^{-1}$.

Comparisons between manure $\mathrm{N}$ treatments were determined for soil $\mathrm{NO}_{3}{ }^{-} \mathrm{N}$ mass in the $0-0.9$ and $0.9-$ $2.1 \mathrm{~m}$ depths within each sampling date. Differences between sampling dates were determined using LSD (least significant difference) for each year, treatment and sampling depth. Significance was determined for all analysis at the 0.05 probability level.

\section{Results and discussion}

\subsection{Grain yields}

There were no differences in corn grain yields between the $\mathrm{N}$ treatments in 2002 and 2003 (Table 2). This is not surprising since the lowest $\mathrm{N}$ application rate was based on the University of Nebraska fertilizer recommendations for corn (Shapiro et al., 2003) and all plots

Table 2. Corn grain yield and analysis of variance from lysimeters for nitrogen treatments in 2002 and 2003

\begin{tabular}{lcc}
\hline & $2002\left(\mathrm{Mg} \mathrm{ha}^{-1}\right)$ & $2003\left(\mathrm{Mg} \mathrm{ha}^{-1}\right)$ \\
\hline $1 \mathrm{M}$ & 12.5 & 10.5 \\
$2 \mathrm{M}$ & 11.4 & 11.2 \\
$1 \mathrm{~F}$ & 10.3 & 10.6 \\
Average & 11.4 & 10.8 \\
Percent of yield goal & 84 & 80 \\
Analysis of variance $(P>F)$ & & \\
N treatment (NT) & 0.346 & 0.721 \\
Previous crop (PC) & 0.655 & 0.882 \\
NT $\times$ PC & 0.550 & 0.695 \\
\hline
\end{tabular}




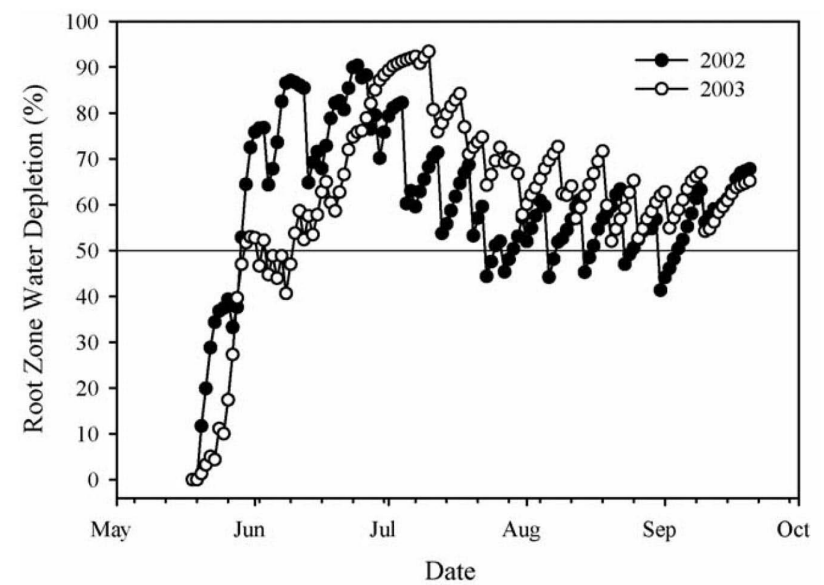

Figure 1. The root zone water depletion in 2002 and 2003 during the growing season based on water balance model.

did not reach the expected yield on which the recommendations were based in either 2002 or $2003\left(13.5 \mathrm{Mg} \mathrm{ha}^{-1}\right)$. Because the yields for each treatment were similar and the same variety was planted over the entire experiment, it is assumed that the $\mathrm{N}$ uptake for all treatments was similar and did not influence differences in nitrate concentrations in the soil and leachate between treatments. The reason the grain yields were not closer to the expected yield at this site was due to water stress. The root zone water depletion in 2002 and 2003 was greater than the $50 \%$ depletion level for 64 and $74 \%$ of the days during the growing season in 2002 and 2003, respectively (Figure 1). This depletion level refers to the point in which $50 \%$ of the total plant available water remains in the root zone, which is commonly used to trigger irrigation under best management practices. To achieve maximum yields not limited by water, the actual soil water depletion needs to be consistently below the $50 \%$ depletion level for the soil. In 2002 and 2003 water stored in the soil at the beginning of the season, irrigation, and precipitation provided enough water to provide 89 and $79 \%$ of the needed ET to achieve non-water limiting yields, respectively (Figure 2). Greater yields in 2002 compared to 2003 when averaged over treatment were due to more water to supply ET in 2002 (Table 2 and Figure 2).

\subsection{Irrigation, soil water, and leachate amounts}

Additional supporting evidence that the grain yield was affected by water stress is shown in Figure 2. The $\mathrm{ET}_{\mathrm{d}}$ was consistently less than the $\mathrm{ET}_{\mathrm{w}}$ for both 2002 and 2003 (Figure 2). This is a result of irrigation not maintaining the root zone depletion level below $50 \%$ consistently through the season (Figure 1).

These results emphasize the importance of managing yield limiting factors to achieve maximum yields (i.e. irrigation scheduling) when $\mathrm{N}$ sources are applied to reach the maximum yields and matching $\mathrm{N}$ inputs to realistic yield potentials due to the increased risk of leaving excessive amounts of $\mathrm{NO}_{3}{ }^{-} \mathrm{N}$ in the soil that will be susceptible to leaching.

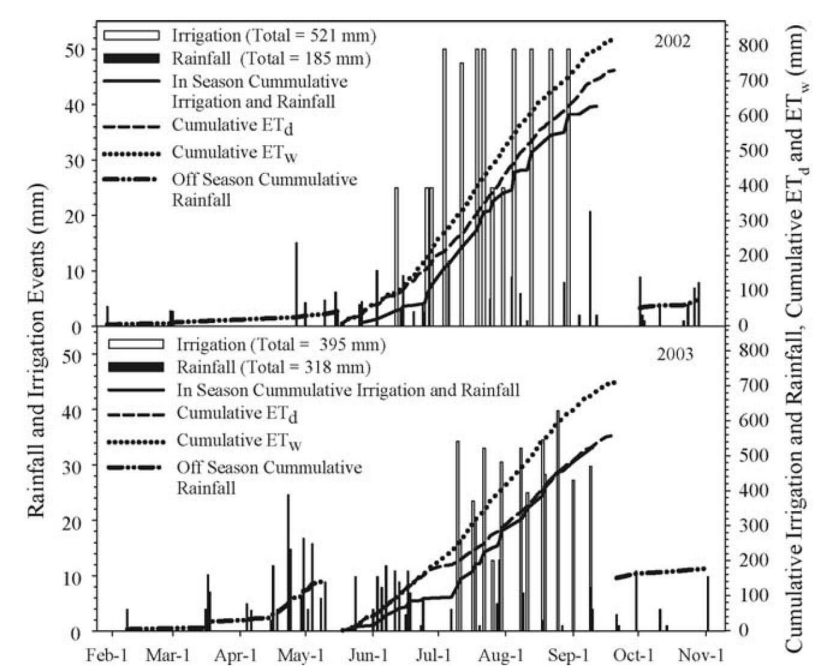

Figure 2. Irrigation, precipitation, and evapotranspiration (ET) data for all research plots in 2002 and 2003. ET is $_{d}$ the actual crop evapotranspiration. $\mathrm{ET}_{\mathrm{w}}$ is the estimated crop evapotranspiration assuming water is not limiting.

The leachate depths collected from the lysimeters were significantly greater in 2003 than in 2002 when averaged over the manure $\mathrm{N}$ treatments $(P>F=0.002$, Table 3 and Table 4). However, in 2002 and 2003 the total cumulative irrigation and precipitation inputs during the year were approximately equal with 706 and $713 \mathrm{~mm}$ for 2002 and 2003, respectively (Figure 2). The greater leachate depth in 2003 was most likely due to greater precipitation in the spring compared to 2002 (Figure 2). This likely led to more leachate movement through the soil profile prior to crop use. A portion of the leachate collected from the lysimeters in 2002 was most likely soil water in the lower part of the soil profile derived from past water inputs. The volumetric soil water content at field capacity in this soil was $0.29 \mathrm{~m}^{3} \mathrm{~m}^{-3}$ (Klocke et al., 1999). The lower depths of the lysimeters had greater volumetric water contents than the surface depths and exceeded field capacity in most lysimeters in early June 2002 based on neutron probe measurements (Figure 3). Preferential flow of water from irrigation and precipitation and stored water below the root zone likely were the sources of water collected from the lysimeters during both years. Research has shown that most water in corn production is extracted in the surface $1.8 \mathrm{~m}$ (Schneekloth et al., 1991). Therefore, water stored below this depth will move to deeper depths as water from the root zone moves down. Under deficit irrigation water from preferential flow could play a role in the overall water movement below the root zone.

From January to June, precipitation totaled 51 and $161 \mathrm{~mm}$ in 2002 and 2003, respectively (Figure 2). The total precipitation in 2002 and 2003 were, 185 and $318 \mathrm{~mm}$, respectively. The lower precipitation in 2002 resulted in greater irrigation applied $(521 \mathrm{~mm})$ compared to 2003 (395 mm) (Figure 2).

The leachate depths averaged over $\mathrm{N}$ treatment were 33 and $102 \mathrm{~mm}$ in 2002 and 2003, respectively. In this 
study, the depth of water leaching through the soil was limited by insufficient precipitation and irrigation to meet corn ET demands in 2002 and 2003. However, in a previous conducted study from 1993 to 1998, the average leachate depth collected from the lysimeters at this site was $218 \mathrm{~mm}$ year ${ }^{-1}$ under full irrigation (Klocke et al., 1999). Thus, the annual leachate depth under deficit irrigation was 15 and 47\% for 2002 and 2003, respectively, compared with that reported under full irrigation (Table 4). There were no differences in leachate depths between the $\mathrm{N}$ treatments and the previous crop did not influence leachate depths (Table 3).

\subsection{Nitrate in leachate and soil}

The concentration and mass loss of $\mathrm{NO}_{3}{ }^{-} \mathrm{N}$ in the leachate were greater in 2003 than 2002 when averaged over the three $\mathrm{N}$ treatments (Tables $3 \& 4$ ). The over application of $\mathrm{N}$ in 2002 and subsequent leaching of excess $\mathrm{NO}_{3}{ }^{-}$-N over time likely resulted in the increased $\mathrm{NO}_{3}{ }^{-}$$\mathrm{N}$ concentrations and mass losses in 2003. Reduced crop uptake of $\mathrm{NO}_{3}{ }^{-} \mathrm{N}$ due to more water stress in 2003 may have also influenced the increased $\mathrm{NO}_{3}{ }^{-} \mathrm{N}$ concentration and mass losses in 2003.

There were significant differences in the concentrations of $\mathrm{NO}_{3}{ }^{-} \mathrm{N}$ in leachate between the $\mathrm{N}$ treatments (Tables 3 \& 4). Mean separations using LSD showed the concentrations of $\mathrm{NO}_{3}{ }^{-}-\mathrm{N}$ were greater from the $2 \mathrm{M}$ treatment compared to the $1 \mathrm{M}$ treatment and there were no differences between the $1 \mathrm{M}$ and $1 \mathrm{~F}$ treatments and the $2 \mathrm{M}$ and $1 \mathrm{~F}$ treatments when averaged over both years. These relationships are highly influenced by $\mathrm{N}$ mineralization from the manure. Due to the great variability associated with $\mathrm{N}$ release from manures, determining the correct mineralization rates of $\mathrm{N}$ from manures can be problematic (Power and Doran, 1984).

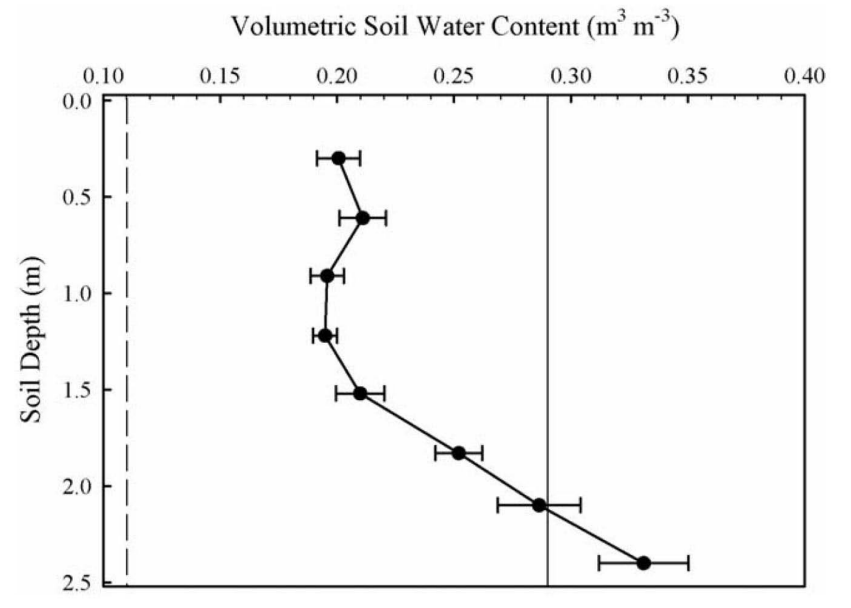

Figure 3. Volumetric soil moisture at different depths in the lysimeters on 2 June 2002. Values at each depth are the average of all 12 lysimeters. Error bars are the standard error of the averages for the 12 lysimeters. Solid vertical line represents the volumetric soil water at field capacity. Dashed line represents the volumetric soil water at permanent wilting point.

There were no differences in mass loss of $\mathrm{NO}_{3}{ }^{-} \mathrm{N}$ in leachate between the three $\mathrm{N}$ treatments when averaged over the 2 years (Tables $3 \& 4$ ). In 2003, there was a trend for greater mass loss of $\mathrm{NO}_{3}^{-}-\mathrm{N}$ in leachate from the $2 \mathrm{M}$ treatment compared to the $1 \mathrm{M}$ and $1 \mathrm{~F}$ treatments (Table 4). The greater losses of $\mathrm{NO}_{3}{ }^{-} \mathrm{N}$ from the $2 \mathrm{M}$ treatment was expected due to the greater application of $\mathrm{N}$.

Although leachate depth and concentration of $\mathrm{NO}_{3}{ }^{-}$ $\mathrm{N}$ were not significantly influenced by previous crop, mass losses (a product of these two factors) in leachate was significantly affected by the previous crop (Table 3 ). In 2003, the mass loss of $\mathrm{NO}_{3}{ }^{-}-\mathrm{N}$ in leachate was significantly higher in the plots cropped to soybean in 2001 than the plots cropped to corn (Figure 4). In 2002, the previous crop did not influence the mass loss of $\mathrm{NO}_{3}{ }^{-} \mathrm{N}$ in leach-

Table 3. Analysis of variance $(P>F)$ for concentration and mass losses of nitrate- $\mathrm{N}$ in leachate and leachate depths collected from lysimeters for $\mathrm{N}$ treatment, previous crop, year, and

\begin{tabular}{lccc}
\hline $\mathrm{N}$ treatment & Leachate depth & $\mathrm{NO}_{3}{ }^{-}$concentrations & $\mathrm{NO}_{3}{ }^{-}$mass losses \\
\hline N treatment (NT) & 0.583 & 0.045 & 0.079 \\
Previous crop (PC) & 0.082 & 0.091 & 0.026 \\
Year $(\mathrm{Y})$ & 0.002 & 0.025 & 0.001 \\
$\mathrm{NT} \times \mathrm{PC}$ & 0.222 & 0.172 & 0.014 \\
$\mathrm{NT} \times \mathrm{Y}$ & 0.799 & 0.261 & 0.038 \\
$\mathrm{PC} \times \mathrm{Y}$ & 0.417 & 0.315 & 0.029 \\
$\mathrm{NT} \times \mathrm{PC} \times \mathrm{Y}$ & 0.942 & 0.359 & 0.042 \\
\hline
\end{tabular}

Table 4. Concentration and mass losses of nitrate-N in leachate and leachate depths collected from lysimeters

\begin{tabular}{|c|c|c|c|c|c|c|c|c|c|}
\hline \multirow[t]{2}{*}{$\mathrm{N}$ treatment } & \multicolumn{3}{|c|}{ Leachate depth (mm) } & \multicolumn{3}{|c|}{$\mathrm{NO}_{3}{ }^{-}$concentrations $\left(\mathrm{mg} \mathrm{L}^{-1}\right)$} & \multicolumn{3}{|c|}{$\mathrm{NO}_{3}^{-}$mass losses $\left(\mathrm{kg} \mathrm{ha}^{-1}\right)$} \\
\hline & 2002 & 2003 & Average & 2002 & 2003 & Average & 2002 & 2003 & Average \\
\hline $1 \mathrm{M}$ & $29.9(15.7)^{\mathrm{a}}$ & $93.9(11.0)$ & ) 61.9 & $15.1(4.6)$ & $18.6(5.9)$ & $16.9 \mathrm{a}^{\mathrm{b}}$ & $15.4(10.0)$ & $48.9(24.9)$ & 9) 32.2 \\
\hline $1 \mathrm{~F}$ & $51.6(29.5)$ & $109.6(30.2)$ & 80.6 & $27.4(8.9)$ & $28.6(7.6)$ & $28.0 \mathrm{ab}$ & $19.4(7.2)$ & $76.5(20.6)$ & 6) 47.9 \\
\hline Average & 33.1 & 102.2 & & 19.7 & 37.8 & & 14.3 & 97.3 & \\
\hline
\end{tabular}

The values for each treatment are the means of four replications.

a Numbers in parentheses are the standard error of the means.

${ }^{b}$ Columns with the same letter are not significantly different based on LSD $(p=0.05)$. 
ate (Figure 4). The increased $\mathrm{NO}_{3}{ }^{-}-\mathrm{N}$ in leachate in 2003 was likely due to less immobilization of soil $\mathrm{NO}_{3}{ }^{-} \mathrm{N}$ in lysimeters cropped to soybean compared to corn (Blackmer, 1997). This decreased immobilization of $\mathrm{NO}_{3}{ }^{-} \mathrm{N}$ following a soybean crop is because there is less residue to be decomposed by soil microbes compared to corn. The soil microbes utilize a greater amount of soil $\mathrm{NO}_{3}{ }^{-} \mathrm{N}$ for amino acid formation during the decomposition of corn residue compared to soybean residue. This difference in $\mathrm{N}$ immobilization is believed to be associated with the soybean credit and is taken into account in many $\mathrm{N}$ fertilizer recommendations for corn in corn-soybean rotations. The higher amount of $\mathrm{NO}_{3}{ }^{-}-\mathrm{N}$ due to reduced immobilization of $\mathrm{NO}_{3}{ }^{-}-\mathrm{N}$ following soybeans is typically credited to the corn crop the year following soybean (2002). However, in this study it took an additional year (2003) for this nitrate to leach below $2.4 \mathrm{~m}$ in the leachate.

In 2003, the mass of $\mathrm{NO}_{3}{ }^{-}-\mathrm{N}$ averaged over all sampling dates and manure treatments in the soil at a depth of $0-0.9 \mathrm{~m}$ was less than in 2002, and at a depth of 0.9$2.1 \mathrm{~m}$ the $\mathrm{NO}_{3}{ }^{-}-\mathrm{N}$ mass was greater than in 2002. These results indicate that $\mathrm{NO}_{3}{ }^{-} \mathrm{N}$ was leaching below the $0.9 \mathrm{~m}$ depth, mineralization rates were decreasing, and the corn plants were utilizing the available $\mathrm{N}$ (Table 5 and Table 6). In 2003, the average mass of $\mathrm{NO}_{3}{ }^{-} \mathrm{N}$ in the $0.9-2.1 \mathrm{~m}$ depth was 37 and $60 \%$ greater for the $1 \mathrm{M}$ and $2 \mathrm{M}$ treatments compared to masses in 2002, respectively. In 2002 and 2003, the $\mathrm{NO}_{3}{ }^{-} \mathrm{N}$ concentrations in leachate exceeded the EPA critical level of $10 \mathrm{mg} \mathrm{L}^{-1}$. In this study under deficit irrigation conditions, where leachate volumes were reduced, over applying $\mathrm{N}$ by $12-24 \%$ (applied $\mathrm{N}$ rate - calculated $\mathrm{N}$ rate based on actual yields) for the $1 \mathrm{M}$ and $2 \mathrm{M}$ treatments, respectively, resulted in $\mathrm{NO}_{3}{ }^{-}-\mathrm{N}$ concentration and mass losses in leachate increasing by 63 and $89 \%$ from 2002 to 2003 when averaged over manure $\mathrm{N}$ treatment.

Previous crop did not influence concentration and mass loss of $\mathrm{NO}_{3}^{-}-\mathrm{N}$ in the soil from field plots adjacent to

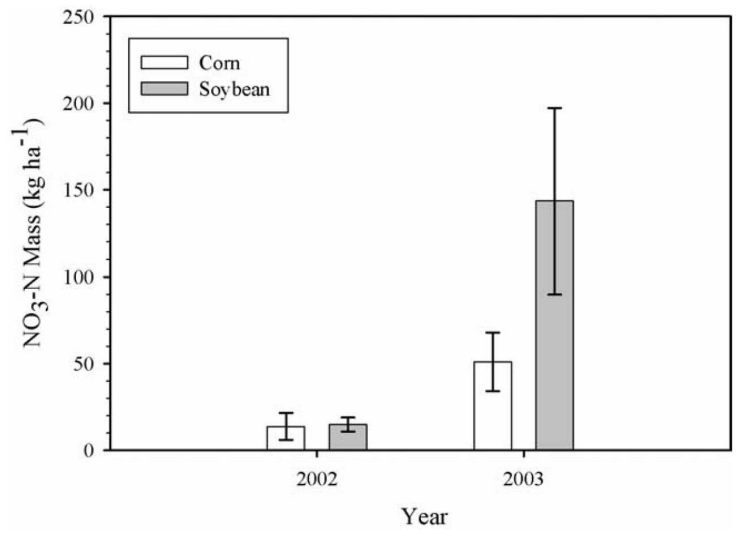

Figure 4. Masses losses of $\mathrm{NO}_{3}{ }^{-} \mathrm{N}$ in leachate from lysimeters in 2002 and 2003 as related to the previous year crop (2001, corn or soybean). For each year the mass losses are averaged over the nitrogen treatments for each previous crop. Error bars are the standard error of the treatment means.

the lysimeters (Table 5). In the surface $0-0.9 \mathrm{~m}$, mass of $\mathrm{NO}_{3}{ }^{-}-\mathrm{N}$ increased after manure was applied for all treatments (Table 6). In the $1 \mathrm{M}$ and $2 \mathrm{M}$ treatments the mass of $\mathrm{NO}_{3}{ }^{-} \mathrm{N}$ increased until the 19 June 2002 and 16 September 2002 sampling dates, respectively. These increases were likely the result of mineralization of the organic $\mathrm{N}$ in the manure and soil organic matter. Declines in the mass of $\mathrm{NO}_{3}{ }^{-} \mathrm{N}$ in the soil for the manure treatments in 2003 compared to 2002 in the $0-0.9 \mathrm{~m}$ depth was probably due to a combination of $\mathrm{NO}_{3}{ }^{-}-\mathrm{N}$ leaching below the $0.9 \mathrm{~m}$ depth, decreased $\mathrm{N}$ mineralization rates from manure, and plant uptake of $\mathrm{N}$. In 2003, there was reduced mineralization occurring in the manure treatments compared to 2002 (Table 6). Due to the higher amounts of manure added, the $2 \mathrm{M}$ treatment had significantly greater, or trends for greater, $\mathrm{NO}_{3}{ }^{-}-\mathrm{N}$ mass in the 0-0.9 m soil depth for most sampling dates after 19 June 2002 compared to the $1 \mathrm{M}$ treatment. After manure applications on May 9, 2002 until June 19, 2002

Table 5. Analysis of variance $(P>F)^{\text {a }}$ for mass losses of nitrate-N in the soil profile from 0 to $0.9 \mathrm{~m}$ and 0.9 to $2.1 \mathrm{~m}$ during periodic sampling dates in 2002 and 2003 for manure $\mathrm{N}$ treatment, previous crop, date, and interaction main effects

\begin{tabular}{|c|c|c|c|}
\hline Sampling dates: & April 11, 2002a & May 31-November 7, 2002 ${ }^{\mathrm{b}}$ & May 1-October 28, 2003c \\
\hline \multicolumn{4}{|l|}{$0-0.9 \mathrm{~m}$} \\
\hline Manure $\mathrm{N}$ treatment (MNT) & 0.420 & $<0.001$ & 0.002 \\
\hline Previous crop (PC) & 0.759 & 0.148 & 0.116 \\
\hline $\mathrm{MNT} \times \mathrm{PC}$ & - & 0.316 & 0.474 \\
\hline MNT × D & - & 0.027 & 0.524 \\
\hline $\mathrm{PC} \times \mathrm{D}$ & - & 0.735 & 0.315 \\
\hline Manure N treatment (MNT) & 0.143 & 0.004 & $<0.001$ \\
\hline Previous crop (PC) & 0.694 & 0.456 & 0.256 \\
\hline Date (D) & 0.455 & 0.236 & 0.014 \\
\hline $\mathrm{MNT} \times \mathrm{PC}$ & - & 0.364 & 0.523 \\
\hline $\mathrm{MNT} \times \mathrm{D}$ & - & 0.651 & 0.169 \\
\hline $\mathrm{PC} \times \mathrm{D}$ & - & 0.266 & 0.697 \\
\hline $\mathrm{MNT} \times \mathrm{PC} \times \mathrm{D}$ & - & 0.485 & 0.899 \\
\hline
\end{tabular}

a Treatment comparison for 11 April 2002 sampling date (pre-treatment application).

${ }^{\mathrm{b}}$ Analysis for post-treatment application sampling dates in 2002.

${ }^{\text {c }}$ Analysis for treatment sampling dates in 2003. 
the $\mathrm{NO}_{3}{ }^{-}-\mathrm{N}$ masses were not different for the manure $\mathrm{N}$ treatments.

From the June 4, 2003 sampling date to the end of the study, the $2 \mathrm{M}$ treatment had greater $\mathrm{NO}_{3}{ }^{-} \mathrm{N}$ mass at the 0.9-2.1 m depth compared to the $1 \mathrm{M}$ treatment. In the 0.9-2.1 m depth the masses of $\mathrm{NO}_{3}{ }^{-}-\mathrm{N}$ from the pre-application sampling date through the 1 May 2003 sampling date remained constant before increasing for both manure $\mathrm{N}$ treatments. These results indicate that, for both manure $\mathrm{N}$ treatments, it took approximately 12-13 months for a sufficiently large quantity of $\mathrm{NO}_{3}^{-}-\mathrm{N}$ from the manure application to reach the $0.9-2.1 \mathrm{~m}$ depth that could be measured as significantly different from previous sampling dates.

The average masses of $\mathrm{NO}_{3}{ }^{-}-\mathrm{N}$ in the soil $(0-2.1 \mathrm{~m})$ after treatment application in 2002 through 2003 for the $1 \mathrm{M}$ and $2 \mathrm{M}$ treatments were 150 and $338 \mathrm{~kg} \mathrm{~N} \mathrm{ha}^{-1}$, respectively. Irrigation water added 31 and $24 \mathrm{~kg} \mathrm{NO}_{3}{ }^{-}-$ $\mathrm{N} \mathrm{ha}^{-1}$ to all manure $\mathrm{N}$ treatments in 2002 and 2003, respectively. Irrigation water had an average $\mathrm{NO}_{3}{ }^{-}-\mathrm{N}$ concentration of $6 \mathrm{mg} \mathrm{L}^{-1}$ for 2002 and 2003.

There was greater concentration and greater movement of $\mathrm{NO}_{3}{ }^{-} \mathrm{N}$ through the soil over time in the $2 \mathrm{M}$ compared to the $1 \mathrm{M}$ treatment (Figure 5). The date and depth main effects and the date $\times$ depth interaction were all significant $(P<0.05)$ (analysis of variance not shown). Mean separations for each date show that very little $\mathrm{NO}_{3}{ }^{-}-\mathrm{N}$ moved below the $0.6-0.9 \mathrm{~m}$ sampling depth for both manure $\mathrm{N}$ treatments in 2002 (Figure 5).

Soil $\mathrm{NO}_{3}^{-}\left(\mathrm{mg} \mathrm{kg}^{-1}\right)$

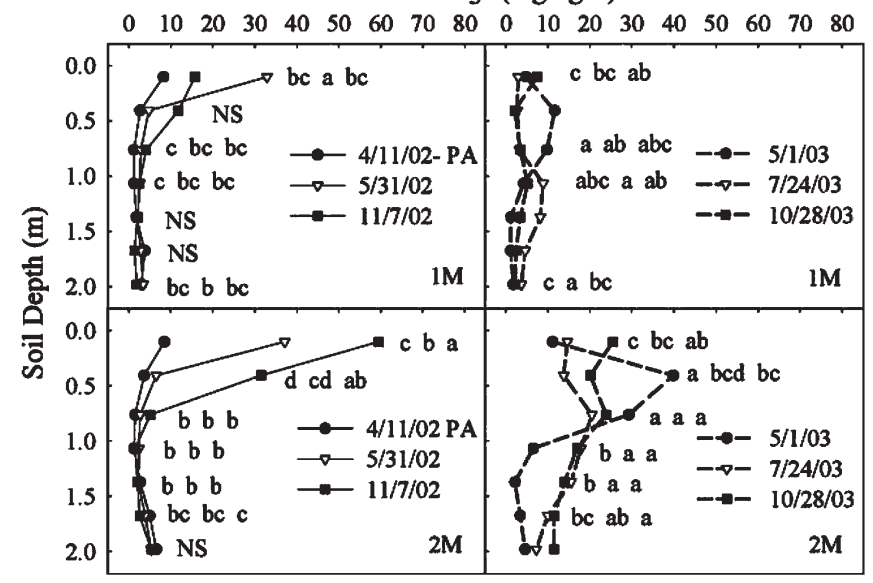

Figure 5. Concentrations of soil $\mathrm{NO}_{3}{ }^{-}-\mathrm{N}$ at depth increments on selected dates in 2002 and 2003 in plots fertilized with beef feedlot manure at the recommended rate for $\mathrm{N}(1 \mathrm{M})$ and at twice the recommended rate for $\mathrm{N}(2 \mathrm{M})$. Each concentration is the average of four replications. PA is the pre-application sampling date. For each manure $\mathrm{N}$ treatment LSD was used to determine differences between sampling dates over both years at each depth when there were significant date main effects at each depth. Dates with the same letter are not significantly different for each depth. Letters from left to right represent dates in ascending chronological order (April 11, 2002-October 28, 2003). Statistical significance was determined at the 0.05 probability level.

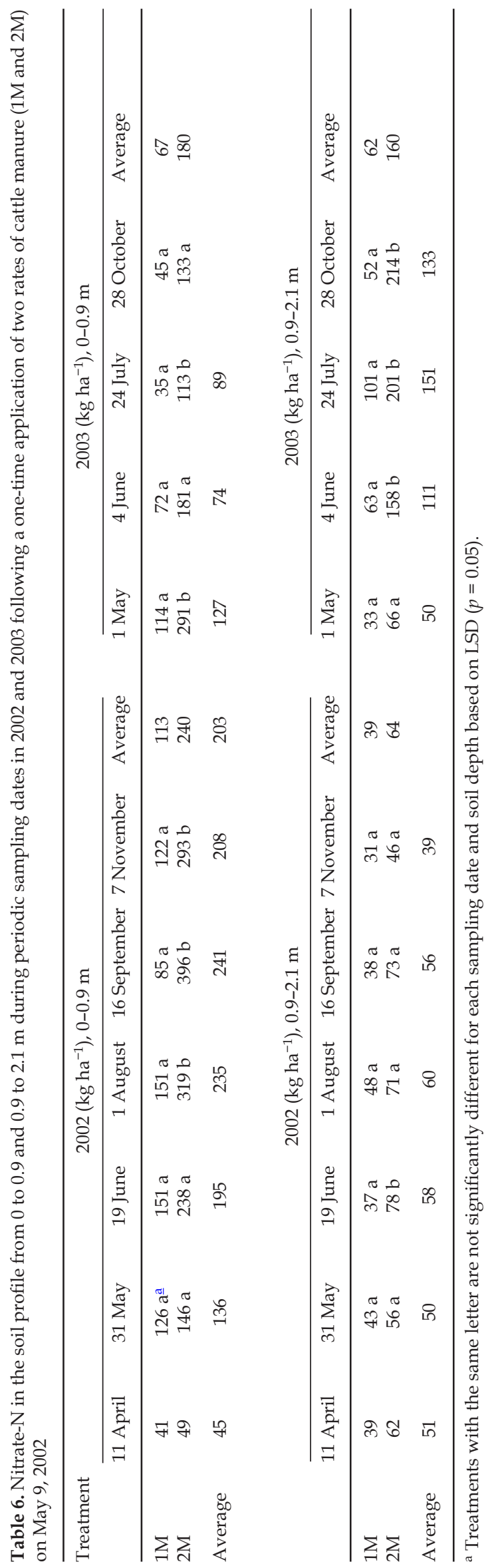


However, in 2003 all treatments show $\mathrm{NO}_{3}{ }^{-}-\mathrm{N}$ movement to a depth of $1.5-1.8 \mathrm{~m}$. At the end of the 2003 growing season the $\mathrm{NO}_{3}^{-}-\mathrm{N}$ masses in the $1.8-2.1 \mathrm{~m}$ depth were still not elevated for both manure $\mathrm{N}$ treatments compared to the pre-application (11 April 2003) $\mathrm{NO}_{3}{ }^{-} \mathrm{N}$ masses. However, the $\mathrm{NO}_{3}{ }^{-} \mathrm{N}$ concentrations in the lysimeter leachate show that some of this $\mathrm{NO}_{3}{ }^{-} \mathrm{N}$ did make it to this depth in the lysimeters due to greater $\mathrm{NO}_{3}{ }^{-}-\mathrm{N}$ masses in 2003 compared to 2002 for both manure $\mathrm{N}$ treatments (Table 3 ).

The greater mass of $\mathrm{NO}_{3}{ }^{-} \mathrm{N}$ in the soil profile for the $2 \mathrm{M}$ treatment could lead to greater loss of $\mathrm{NO}_{3}^{-}-\mathrm{N}$ in leachate in the future, even under deficit irrigation. If manure application rates exceed plant requirements $\mathrm{NO}_{3}{ }^{-}-\mathrm{N}$ can leach under deficit water input conditions. The $\mathrm{NO}_{3}{ }^{-}-\mathrm{N}$ mass in the soil from the $2 \mathrm{M}$ treatment was $45 \%$ greater than the $1 \mathrm{M}$ treatment when averaged over all sampling dates and depths during 2002.

\section{Conclusions}

An over application of $\mathrm{N}$ to the soil in 2002 resulted from insufficient irrigation applications to reach expected corn grain yields. Water available to the crop was sufficient to meet 89 and $79 \%$ of the potential crop ET in 2002 and 2003, respectively. Under these conditions leachate depths were only 15 and $47 \%$ in 2002 and 2003, respectively, compared to data previously reported for years in which the crop was fully irrigated. Even with reduced leachate volume, the $\mathrm{NO}_{3}{ }^{-} \mathrm{N}$ from both manure $\mathrm{N}$ treatments leached through the soil profile and increased mass of $\mathrm{NO}_{3}{ }^{-} \mathrm{N}$ in leachate by an average of $88 \%$ from 2002 to 2003 . This research shows that there can be $\mathrm{NO}_{3}{ }^{-} \mathrm{N}$ losses when manure $\mathrm{N}$ is over applied and water movement can occur below the crop root zone under deficient irrigation. The leachate losses were likely related to water initially stored below the root zone and possibly preferential flow of water from irrigation and precipitation.

Manure applied at twice the recommended rate under deficit irrigation resulted in greater $\mathrm{NO}_{3}{ }^{-}-\mathrm{N}$ mass in the soil and greater movement of $\mathrm{NO}_{3}{ }^{-} \mathrm{N}$ compared to manure applied at the recommended $\mathrm{N}$ rate under deficit irrigation. It is important to account for reduced immobilization of $\mathrm{N}$ after soybean compared to corn. For producers to minimize the potential risk of over application of $\mathrm{N}$, they need to match $\mathrm{N}$ inputs with crop needs. Producers who use $\mathrm{N}$ recommendations that utilize realistic corn yield goals can balance $\mathrm{N}$ inputs and crop need by adjusting the yield goal to account for deficit irrigation. This process can be problematic because prediction of in-season rainfall amounts is difficult. Most producers are hesitant to reduce manure $\mathrm{N}$ application rates to account for deficit irrigation because they may under apply $\mathrm{N}$ if water inputs from in-season precipitation are higher than expected and thus reduce yield po- tential and economic profits. To better match manure $\mathrm{N}$ application rates to crop needs under deficit irrigation, continued research is needed to better predict seasonal weather patterns and precipitation, and develop crop yield versus water response functions on a site-specific basis. At the present time, producers can better match manure $\mathrm{N}$ application rates with crop needs by using a variety of practices. Over application of $\mathrm{N}$ from manure can be avoided by applying a reduced pre-season manure application rate (less than 100\% of crop requirement). This can be supplemented by in-season commercial $\mathrm{N}$ applications based on the quantity of in-season precipitation and/or use of measurements of plant $\mathrm{N}$ status (e.g. tissue tests, chlorophyll meter readings). Also, the use of adequate irrigation scheduling techniques can be used and developed to avoid deep percolation of excess water and $\mathrm{NO}_{3}{ }^{-}-\mathrm{N}$. Choosing the correct availability factor for organic $\mathrm{N}$ in solid manures is also critical in this process.

Continued research is needed to assess more factors influencing the potential for $\mathrm{NO}_{3}{ }^{-} \mathrm{N}$ leaching in soils under deficit irrigation in production agriculture and to improved irrigation scheduling techniques.

\section{References}

Allen et al., 1998 R. G. Allen, L. S. Pereira, D. Raes, and M. Smith, Crop evapotranspiration - guidelines for computing crop water requirements, Irrigation and Drainage Paper No. 56, FAO, Rome, Italy, 1998.

Analytical and Software, 2003 Analytical and Software, Statistix 8, Analytical and Software, Tallahassee, FL (2003).

Blackmer, 1997 A. M. Blackmer, Soil Fertility: What About $N$ Credits Following Soybean?, Iowa State University, Integrated Crop Management IC-478-R7, Ames, IA (1997) online: verified April 6, 2006; http://www.ipm.iastate.edu/ $\mathrm{ipm} / \mathrm{icm} / 1997 / 6-16-1997 /$ ncredsoyb.html

Bremner and Mulvaney, $1982 \longrightarrow$ J. M. Bremner and C. S. Mulvaney, Nitrogen-total. In: A. L. Page, Editor, Methods of Soil Analysis. Part 2. Chemical and Microbiological Properties (2nd ed.), ASA and SSSA, Madison, WI (1982), pp. 595-624.

Chang and Janzen, 1996 C. Chang and H. H. Janzen, Longterm fate of nitrogen from annual feedlot manure applications, J. Environ. Qual. 25 (1996), pp. 785-790.

Eghball, 1998 B. Eghball, Composting Manure and Other Organic Residues, University of Nebraska-Lincoln Cooperative Extension (1998) NebGuide G97-1315-A.

Ferguson et al., $1991 \rightarrow$ R. B. Ferguson, C. A. Shapiro, G. W. Hergert, W. L. Kranz, N. L. Klocke, and D. H. Krull, Nitrogen and irrigation management practices to minimize nitrate leaching from irrigated corn, J. Prod. Agric. 4 (1991), pp. 86-192.

Gosselin et al., 1997 D. C. Gosselin, J. Headrick, R. Tremblay, X. H. Chen, and S. Summerside, Domestic well-water quality in rural Nebraska: focus on nitrate-nitrogen, pesticides, and coliform bacteria, Ground Water Mon. Remed. 17 (1997), pp. 77-87. 
Hartz et al., 2000 T. K. Hartz, J. P. Mitchell, and C. Giannini, Nitrogen and carbon mineralization dynamics of manures and composts, Hort. Sci. 35 (2000), pp. 209-212.

Jokela, 1992 W. E. Jokela, Nitrogen fertilizer and dairy manure effects on corn yield and soil nitrate, Soil Sci. Soc. Am. J. 56 (1992), pp. 148-154.

Keeney, 1982 D. R. Keeney, Nitrogen management for maximum efficiency and minimum pollution. In: F. J. Stevenson, Nitrogen in agricultural soils. Agron. Monograph 22. ASA, CSSA, SSSA, Madison, WI, 1982; pp. 605-649.

Keeney and Nelson, $1982 \rightarrow$ D. R. Keeney and D. W. Nelson, Nitrogen: inorganic forms. In: A. L. Page, Editor, Methods of Soil Analysis. Part 2. Chemical and Microbiological Properties (2nd ed.), ASA and SSSA, Madison, WI (1982), pp. 643-698.

Klausner et al., 1994 S. D. Klausner, V. R. Kanneganti, and D. R. Boulin, An approach for estimating a decay series for organic nitrogen in animal manure, Agron. J. 86 (1994), pp. 897-903.

Klocke et al., $1999 \rightarrow$ N. L. Klocke, D. G. Watts, J. P. Schneekloth, D. R. Davison, R. W. Todd, and A. M. Parkhurst, Nitrate leaching in irrigated corn and soybean in a semi-arid climate, Trans. ASAE 42 (1999), pp. 1621-1630.

Klocke et al., 1993 N. L. Klocke, R. W. Todd, G. W. Hergert, D. G. Watts, and A. M. Parkhurst, Design, installation, and performance of percolation lysimeters for water quality sampling, Trans. ASAE 36 (1993), pp. 429-435.

Koelsch and Shapiro, $2006-R$. Koelsch and C. Shapiro, Determining crop available nutrients from manure. University of Nebraska-Lincoln Cooperative Extension. NebGuide G97-1335-A, 2006. Verified April 6, 2006, available online: http://www.ianrpubs.unl.edu/epublic/live/g1335/ build/g1335.pdf

Lingle and Franti, $1998 \rightarrow$ G. R. Lingle and T. G. Franti, What is the "Cooperative Agreement" for Endangered Species habitat along the Central Platte River. University of Nebraska-Lincoln Cooperative Extension, NebFact NF98-375, 1998.

McGuire, 2004 V. L. McGuire, V. L., Water-level changes in the High Plains Aquifer, predevelopment to 2002, 1980-2002 and 2001-2002. Fact Sheet 2004-3026, U.S. Geological Survey, Lincoln, 2004.

McGuire and Fischer, 1999 V. L. McGuire and B. C. Fischer, Water-level changes, 1980-1997 and saturated thickness, 19961997, in the High Plains Aquifer. Fact Sheet 124-99, U.S. Geological Survey, Lincoln, 1999.
MidWest Plan Service, 1998 MidWest Plan Service, Livestock Waste Facilities Handbook (3rd ed.), MWPS-18, Ames, IA (1998).

NDEQ, 2005 NDEQ, 2005. Title 130: Livestock waste control regulations. Lincoln, NE, verified April 6, 2006, available on-line: http://0-www.sos.state.ne.us.library.unl.edu/ business/regsearch/Rules/Environmental_Quality_Dept of/Title-130.pdf

Owens et al., $1995 \rightarrow$ L. B. Owens, W. M. Edwards, and M. J. Shipitalo, Nitrate leaching through lysimeters in a corn-soybean rotation, Soil Sci. Soc. Am. J. 59 (1995), pp. 902-907.

Payero et al., 2005 J. O. Payero, S. R. Melvin, and S. Irmak, Response of soybean to deficit irrigation in the semi-arid environment of West-Central Nebraska, Trans. ASAE 48 (2005), pp. 2189-2203.

Payero et al., 2006 J. O. Payero, S. R. Melvin, S. Irmak, and D. D. Tarkalson, Yield response of corn to deficit irrigation in a semiarid environment, Agric. Water Manage 84 (2006), pp. 101-112.

Payero and Irmak, in press J. O. Payero and S. Irmak, Variable upper and lower crop water stress index baselines for corn and soybeans. Irr. Sci. (in press).

Power and Doran, 1984 J. F. Power and J. W. Doran, Nitrogen use in crop production. In: H. D. Hauck, Editor, Nitrogen in Crop Production, ASA, CSSA, SSSA, Madison, WI (1984), p. 589.

Schneekloth et al., 1991 J. P. Schneekloth, N. L. Klocke, G. W. Hergert, D. L. Martin, and R. T. Clark, Crop rotations with full and limited irrigation and dryland management, Trans. ASAE34 (1991), pp. 2372-2380.

Shapiro et al., $2003 \rightarrow$ C. A. Shapiro, R. B. Ferguson, G. W. Hergert, A. R. Dobermann, and C. S. Wortmann, Fertilizer suggestions for corn. University of Nebraska, NebGuide G74-174-A. Lincoln, NE, 2003. Verified April 6, 2006, online: http://www.ianrpubs.unl.edu/epublic/live/g174/ build/g174.pdf

USDI, 1999 United States Department of the Interior, $\mathrm{Ni}$ trate and Nebraska's small community and rural domestic water supplies: an assessment of problems, needs, and alternatives, 1999.

Wright, 1982 J. L. Wright, New evapotranspiration crop coefficients, J. Irr. Drain. Div. ASCE 108 (1982), pp. 57-74. 